\title{
Mitos Rabo Wekasan di Gunung Tanjung Tegal
}

\author{
Oleh: Fathurozi \\ Staf Balai Penelitian dan Pengembangan Agama Semarang
}

Ratusan anak-anak, remaja hingga orang dewasa berbondong-bondong menghadiri acara
tahunan Rebo Wekasan di gunung Tanjung, Lebaksiu, Tegal, Jawa Tengah. Pengunjung
berasal dari Tegal, Brebes, dan Purwokerto, bahkan ada yang datang dari Jakarta. Mereka
mengikuti kegiatan Haul Mbah Panggung. Namun ada yang semata-mata mencari jodoh,
penglaris $\quad$ dagangan

Pagi itu terlihat masyarakat beriring-iringan melewati jembatan yang memiliki panjang kirakira 200 meter. Jembatan ini merupakan penghubung antara pemukiman penduduk dengan gunung Tanjung. Iring-iringan tersebut membawah nasi onggal-anggil atau nasi kuning menuju makam Mbah Panggung yang berada diatas bukit. Sepanjang jalan munuju puncak di kanan-kiri dipenuhi pedagang kaki lima. Tak jauh dari bukit terdengar sayup-sayup suara gendingan Jawa, rupanya sumber suara itu dari pagelaran wayang kulit.

Tradisi seperti ini dilakukan masyarakat Lebaksiu Lor dan warga Kabupaten Tegal, tiap hari Rabu-Minggu terakhir di bulan Safar. Berhenti sejenak melepas lelah sambil menikmati pemandangan rimbunnya pepohonan kayu Jati dan Pinus.

Jalan setapak dan terjal tak mengurungkan niat sedikitpun menghadiri tradisi ini. Kepercayaan yang berkembang di masyarakat, bulan Safar adalah bulan bencana. Tak ayal masyarakat melaksanakan rebo wekasan agar terhindar dari bencana. Konon kepercayaan ini dilakukan turun temurun, tak heran jika saat ini tradisi ini memikat masyarakat luas.

Tiap Rabo wekasan tiba, warga Tegal memotong sehelai rambut dengan tujuan menolak bala dan membagikan bubur merah putih ke beberapa tetangga, mereka percaya jika ritual semacam itu tak dilakukan maka bencana akan menimpa mereka.

\section{Rabo Wekasan}

Rebo Wekasan adalah tradisi masyarakat Muslim khususnya Jawa. Rebo Wekasan diambil dari nama hari Rabu terakhir di bulan Safar. Rebo Wekasan sering didengung-dengungkan masyarakat sebagai hari bencana, bahkan seakan-akan menjadi kepercayaan. Tak heran bila bulan Safar tiba, setiap keluarga melakukan ritual mulai mandi di sungai dan membuat jajanan pasar.

Dalam buku Kanzun Najah was-Suraar fi Fadail al-Azmina wasy-Syuhaar karya Imam Abdul Hamid Quds, mufti. Dia mengatakan pada bulan Safar Banyak Awliya Allah yang mempunyai Pengetahuan Spiritual telah menandai bahwa setiap tahun, 320 ribu penderitaan (Baliyyat) jatuh ke bumi pada hari Rabu terakhir di bulan Safar.

Hari rabo di bulan ini berbeda dengan hari rabo dibulan-bulan lain karena hari itu dianggap hari kutukan. Menurut Hamid Hari yang sangat berat dibandingkan hari-hari lain sepanjang tahun. Banyak ulama mengatakan bahwa ayat al-Quran, "Yawma Nahsin Mustamir" yakni "Hari berlanjutnya pertanda buruk" merujuk pada hari ini.

\section{Mitos}

Pengunjung yang hadir pada rabo wekasan di gunung Tanjung memiliki berbagai niat ada yang beringin mencari jodoh, naik pangkat, penglaris hingga mendapatkan pekerjan karena Gunung tanjung dipercaya sebagai tempat keramat cukup ampuh mengabulkan permintaan. 
Agar permohonan dikabulkan konon pengunjuing diharuskan melewati jembatan penghubung antara kampung dengan gunung Tanjung atau biasa sebut jembatan Sunglon. Mereka turun ke sungai lalu mandi tepat di bawah jembatan tersebut.

Setelah melakukan ritual itu, permintaan akan di kabulkan atau dipenuhi tapi jika belum mendapatkannya, mereka akan naik ke puncak lalu menaburkan bunga ke makam keramat dan bersemidi memanjatkan permohonannya.

Perayaan tradisi rabo wekasan di gunung Tanjung sangat di nanti berbagai kalangan masyarakat. Banyak orang datang tiap tahun, karena permohonan selalu dikabulkan. Sejatinya umat Islam tak mengenal bulan sial atau bencana. Sebaiknya masyarakat memperbanyak sedekah dan melakukan amalan shaleh yang lain.

https://cu2bumi.blogspot.com/2013/05/mitos-rabo-wekasan-di-gunung-tanjung.html 